\title{
Assessment of Key Factors of the Foreign Exchange Rate Formation in Armenia
}

\author{
E.M. Sandoyan , M.A. Voskanyan ${ }^{\mathrm{b}}$, A.G. Galstyan ${ }^{\mathrm{c}}$, \\ Russian-Armenian (Slavonic) University, \\ Yerevan, Armenia \\ ${ }^{\text {a }}$ https://orcid.org/0000-0002-2848-4946; ${ }^{b}$ https://orcid.org/0000-0002-5417-6648 \\ chttps://orcid.org/0000-0002-7800-7232
}

\begin{abstract}
Usually, it is difficult for developing countries to choose a currency regulation policy because of institutional inadequacy, including a significant level of concentration in commodity markets, and a high degree of dependence of the national market and financial system on exogenous factors and a huge external debt.

This article is dedicated to the analysis and evaluation of key factors affecting the formation of the Armenian national currency (dram) exchange rate, as well as to the choice of the currency regulation policy in Armenia. The authors carried out a statistical and econometric analysis of the factors of the foreign exchange rate formation, taking into account the specifics of the transition economy as a whole, as well as the features of the Armenian economy, in particular.

The authors have identified the exogenous and endogenous factors of the foreign exchange rate formation of the dram, depending on the inflow and outflow of foreign currency. Further, the authors specified the influence of dominant factors on the choice of the currency regulation policy in the country.

The authors carried out an econometric analysis of the factors identified at the first stage of the study using the VAR model. The results obtained from this model proved the hypothesis of the non-market nature of the dram's exchange rate formation. The authors concluded that the dram's exchange rate formation has non-market nature because of significant intervention on the currency market by the "monetary authorities".

The key conclusion of this study is the thesis about the need to change the approaches to currency regulation in Armenia in favour of the transition to a free-floating exchange rate policy in order to stimulate sustainable rates of economic growth in the long term.
\end{abstract}

Keywords: currency policy; exchange rate; economic growth; models of exchange rate formation; Armenia

For citation: Sandoyan E.M., Voskanyan M.A., Galstyan A.G. Assessment of key factors of the foreign exchange rate formation in Armenia. Finansy: teoriya i praktika = Finance: Theory and Practice. 2018;22(5):27-39. (In Russ.). DOI: 10.26794/2587-5671-2018-22-5-27-39

\section{Оценка ключевых факторов формирования обменного курса в Армении}

\author{
Э.М. Сандоян ${ }^{\mathrm{a}}$, М.А. Восканян ${ }^{\mathrm{b}}$, А.Г. Галстян ${ }^{\mathrm{C}}$, \\ Российско-Армянский (Славянский) университет, \\ Ереван, Армения \\ ${ }^{\text {a }}$ https://orcid.org/0000-0002-2848-4946; ${ }^{b}$ https://orcid.org/0000-0002-5417-6648 \\ c https://orcid.org/0000-0002-7800-7232
}

\begin{abstract}
АННОТАЦИЯ
Выбор политики валютного регулирования в развивающихся странах, как правило, осложняется институциональной несостоятельностью экономики, в том числе значительной концентрацией на товарных рынках и высокой степенью зависимости национального рынка и финансовой системы от экзогенных факторов и значительного внешнего национального долга.

Данная статья посвящена анализу и оценке ключевых факторов, воздействующих на формирование обменного курса армянской национальной валюты (драма), а также на выбор политики валютного регулирования в Армении. Авторами проведен статистический и эконометрический анализ факторов формирования валютного курса с учетом специфики транзитной экономики в целом, а также особенностей экономики Армении в частности.

Выявлены экзогенные и эндогенные факторы формирования обменного курса драма в зависимости от притока и оттока иностранной валюты. Оценено воздействие доминирующих факторов на выбор политики валютного регу-
\end{abstract}


лирования в стране. В результате исследования авторы приходят к выводу о нерыночном характере формирования обменного курса драма и значительном влиянии на валютный рынок «денежных властей».

Проведен также эконометрический анализ выделенных на первом этапе исследования факторов с использованием VAR модели. Построенная модель доказывает гипотезу о нерыночном характере формирования обменного курса драма.

Ключевым выводом исследования является тезис о необходимости смены подходов к валютному регулированию в Армении в пользу перехода к политике свободно плавающего валютного курса с целью стимулирования устойчивых темпов экономического роста в долгосрочной перспективе.

Ключевые слова: валютная политика; обменный курс; экономический рост; модели формирования обменного курса; Армения

Для цитирования: Sandoyan E.M., Voskanyan M.A., Galstyan A.G. Assessment of Key Factors of the Foreign Exchange Rate Formation in Armenia. Финансы: теория и практика. 2018;22(5):27-39. DOI: 10.26794/2587-5671-2018-22-5-27-39

\section{INTRODUCTION}

Despite significant changes in the size and structure of the inflow and outflow of foreign currency in Armenia, implementation of the currency policy, especially from 2014 to the present, aimed at keeping the national currency exchange rate stable has led to a significant loss of the export potential of the economy. For example, due to "achievement" of the most stable exchange rate of the Armenian dram in comparison with the national currencies in the EAEU countries, given the significant devaluation of the latter (especially the Russian and the Belarusian rubles), Armenia's domestic goods and services lost their competitive advantages in the common Eurasian market. Armenia's accession to the Customs Union was associated with high hopes for expanding exports from Armenia through simplification of customs procedures and harmonization of the member countries' legislation in order to develop interstate trade relations. Meanwhile, an adequate currency policy based on the implementation of a floating exchange rate policy could provide significant growth in exports to the Russian Federation. Moreover, given the embargo policy implemented by the West towards the Russian Federation, it could open new niches for Armenian products in the Russian market. Overall, this would neutralize the negative (both social and financial) repercussions of devaluation.

It also should be noticed that due to inefficient monetary policy and currency regulation the Central Bank of Armenia failed to build the confidence of the population and financial market participants in the national currency, which is proved by the high degree of dollarization of household savings and money supply as a whole.

Finally, restraining money supply by monetary policy mechanisms and maintaining a stable exchange rate of the national currency by using unprecedentedly high rates of reserve requirement on foreign currency liabilities caused a slowdown in economic growth over the past 9 years, which intensified the negative conse- quences of the global and regional crises of 2008-2009 and 2014-2015 for Armenia. Apparently, Armenia needs to revise its currency policy, and in order to develop an adequate approach, first of all, it is necessary to assess the key factors that affect the exchange rate.

\section{KEY FACTORS AFFECTING THE FOREIGN EXCHANGE RATE IN ARMENIA}

There are many factors that influence the exchange rate of the national currency. In addition, each country has its own potential and specifics of economic development in a certain period of time. Being a country with a small open economy, Armenia is highly dependent on external factors, in terms of the currency market as well. Given Armenia's quite weak export potential, which is usually one of the main channels for the inflow of foreign currency into the country, other channels of foreign exchange inflows can be identified: foreign direct investment, both international money transfers and remittances.

As it is known, exchange rate formation depends on the structure of the money supply that varies by the outflow and inflow of foreign currency, as well as the operations of a central bank in the open market, including currency interventions. The currency structure of monetary aggregates is also influenced by the mechanisms of banking regulation, especially reserve requirement for bank obligations and the currency position rationing.

A specific feature of the Armenian economy is the role of remittances, the annual volume of which averages about $20 \%$ of GDP. Being an entirely exogenous factor, the inflow of remittances mainly depends on the economic situation in donor countries and, accordingly, the volume of the inflow significantly decreases during crises in the countries. The latter influences the currency structure of monetary aggregates in Armenia, thus the national currency. In addition, remittances constitute a large share in income and play an impor- 


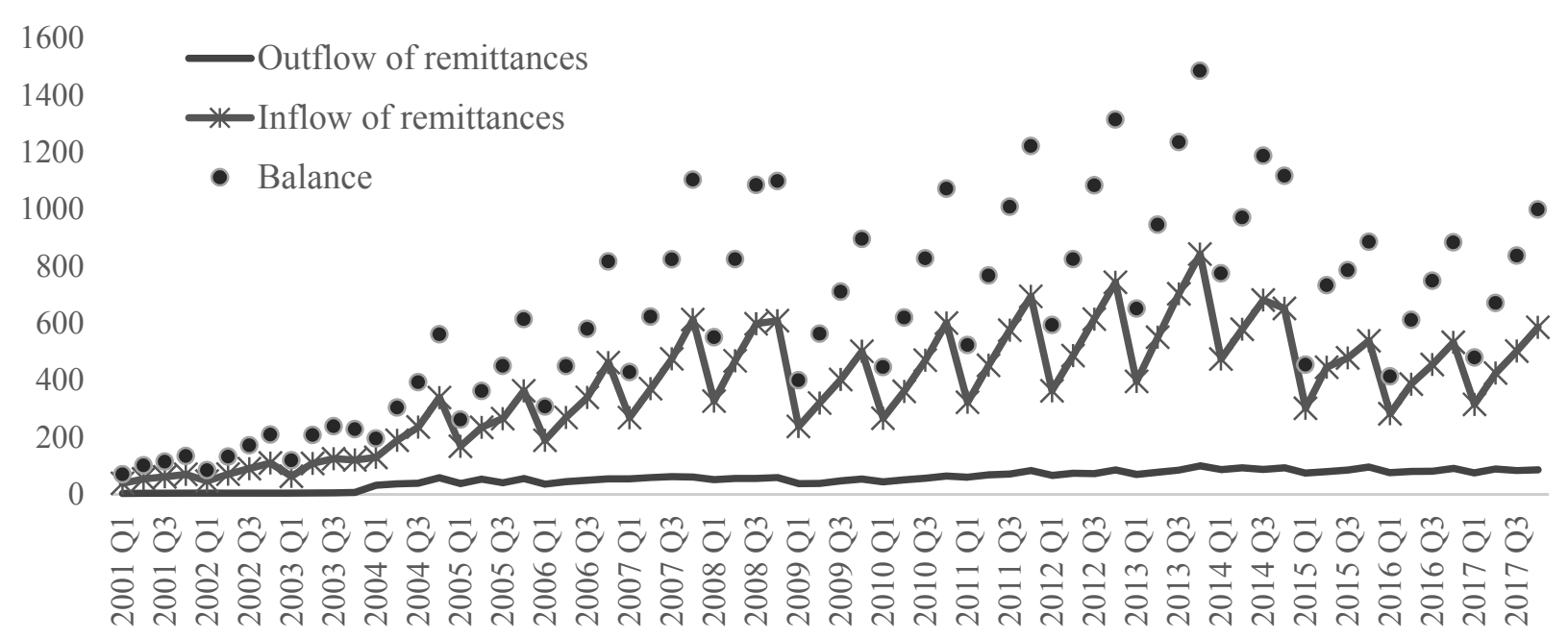

Fig. 1. Inflow and outflow of remittances in Armenia, by a quarter in mln USD

Source: Database of the Central Bank of RA. URL: http://www.cba.am/ (accessed 27.09.2018).

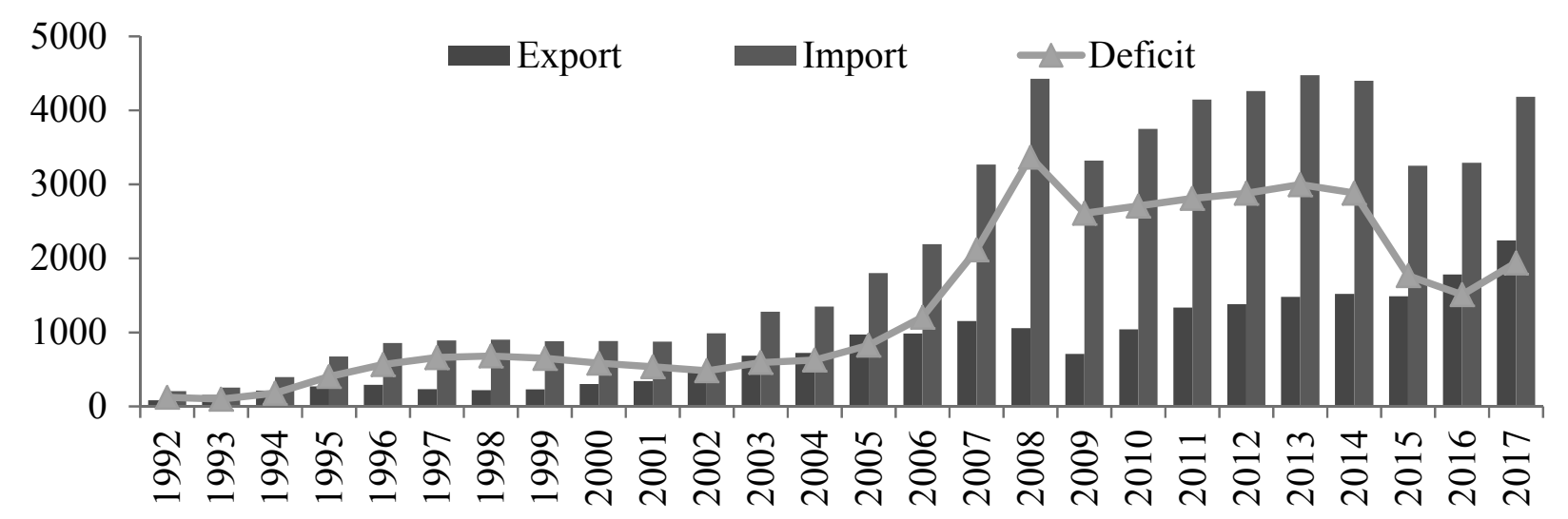

Fig. 2. Exports and imports, by a quarter in mln USD

Source: Database of the Central Bank of RA. URL: http://www.cba.am/ (accessed 27.09.2018).

tant role in the formation of the aggregate demand of the population.

Fig. 1 shows that before the crisis of 2008 the volume of remittances to Armenia had been steadily growing, which, due to the increase in the disposable income of the population, along with positive effects causes inflationary pressure on the consumer market and creates traditional risks of "Dutch disease" for Armenia. In fact, at the beginning of 2009, the negative consequences came quickly. The inflow of remittances to the country drastically decreased, first of all, due to the economic crisis in donor countries.

The worldwide decrease in disposable income led to a reduction of remittances to the economy of Armenia. In its turn, this caused a reduction in the supply of foreign currency in the country, which affected the exchange rate of the national currency. Indeed, in 2009 remittances amounted to 1,124 million US dol- lars ${ }^{1}$ against 1,635 million US dollars in 2008. Such a reduction in the inflow of foreign currency led to instability in the money market and triggered additional inflationary pressures, which was also accompanied by negative inflation expectations from the private sector. Another period of reduction in remittances was observed in 2014, caused, first of all, by the crisis in Russia that has a dominant share in the inflow of remittances to Armenia. However, the dynamics of remittances is not always consistently reflected in the volatility of the exchange rate of the Armenian dram, which also indicates the artificial nature of exchange rate formation in Armenia. Yet, a significant reduction or growth in the inflow and outflow of remittances,

\footnotetext{
${ }^{1}$ Source: The data of the official website of the National Statistical Service of the Republic of Armenia is used. URL: www.armstat.am (accessed 27.09.2018).
} 


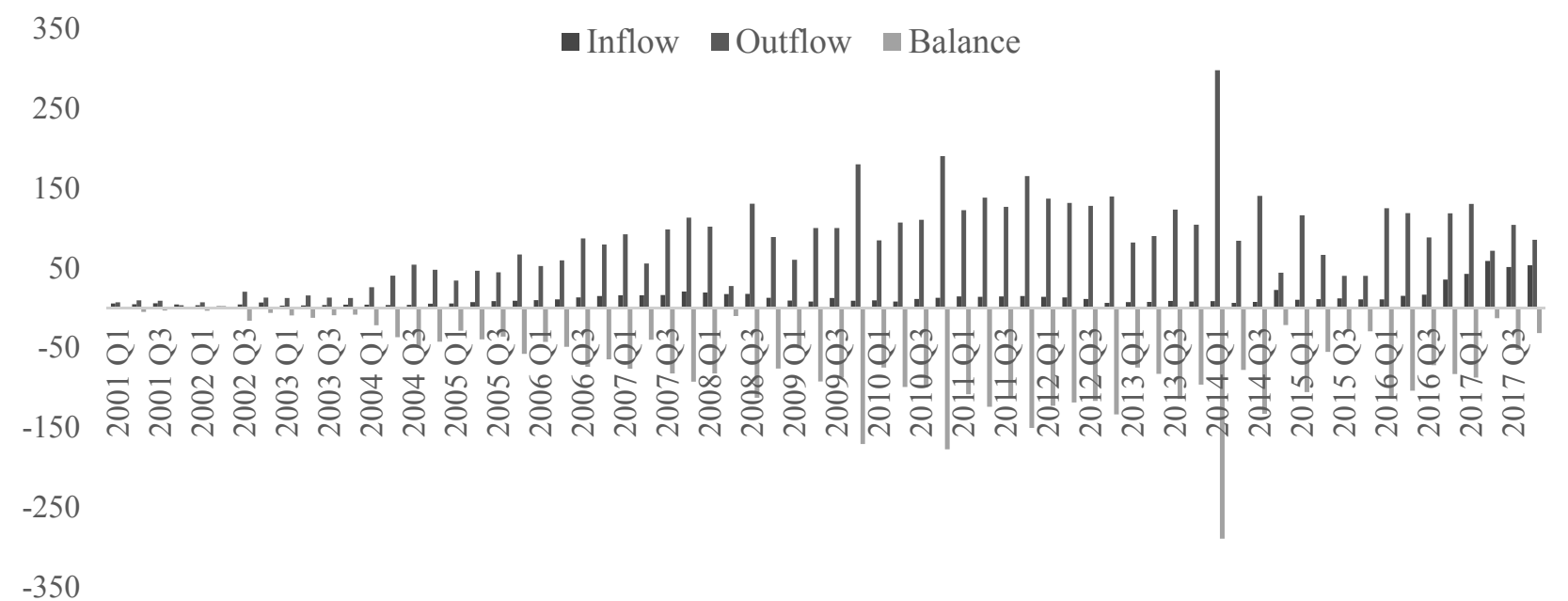

\section{Fig. 3. Investment inflow and outflow, balance (capital flight)}

Source: Database of the Central Bank of RA. URL: http://www.cba.am/ (accessed 10.09.2018).

taking into account their large share in the national economy, cannot but affect the economic growth, even if this influence is indirect, i.e. through disposable income and savings. Thus, this is also one of the most important channels of influence on the exchange rate of the Armenian dram.

The balance of payments has a direct impact on the volatility and value of the exchange rate of the national currency. A positive balance of payments leads to stabilization of the exchange rate, and, vice versa, a negative balance leads, among other things, to destabilization in the foreign exchange market. Firstly, this concerns the trade balance, since exports are considered to be the most effective way of attracting foreign exchange into an economy, especially in terms of long-term economic development.

Throughout the period of independence, the economy of Armenia has been highly import-dependent and is characterized by a significant negative balance of trade (fig. 2). It is remarkable that the trade balance reached a negative peak in the pre-crisis year - the year of 2008 when the highest GDP was recorded in Armenia (and it is still considered to be the highest in the history of the Republic of Armenia). At the same time, 2008 accounts also for the highest volume of net inflow of remittances and foreign direct investments for 2008-2018. Thus, the increase in disposable income of the population due to the growth in the inflow of remittances correlates with the growth in the volume of imports and, vice versa, the reduction in their net inflows almost directly affects the decrease in imports (as happened, for example, in 2009, 2015 and 2016). Without going into detail on the foreign trade specifics of the Armenian economy, one should pay attention to the strict dependence of the trade balance on the volumes of the net inflow of remittances.
It is worth mentioning that Armenia's balance of payments largely depends on fluctuations in the economy of Russia, and not only in terms of remittances. Russia also accounts for large shares in foreign direct investment in Armenia and exports from Armenia. Therefore, changes in the currency market of Russia in the years of crisis, in particular, devaluation of the Russian ruble, had an impact on the competitiveness of Armenian products exported to Russia and Russian products in Armenia. In addition to the devaluation of the Russian national currency, the competitiveness of Armenian goods in the Russian market also declined due to a reduction in domestic consumer demand. Many Armenian commodity producers suspended their exports to Russia in 2015-2016, others significantly reduced it in order not to lose their niche in the commodity market in Russia.

Thus, when the Central Bank of Russia carries out a free-floating exchange rate policy, while the Central Bank of Armenia continues to maintain a stable exchange rate, despite the high volatility of the net inflow of foreign currency, the macroeconomic environment restrains the economic growth. In such conditions, Armenia's export potential has significantly dropped, as the main directions of Armenian exports are Eurasian countries, primarily the Russian Federation.

In the same crisis periods and for the same reasons, direct investments from Russia into Armenia also declined (see fig. 3).

It is also necessary to take into account the traditional channel of the foreign currency outflow - the illicit financial outflow, which is generally formed by the difference between the prices of sales to the final buyer (world prices) and the prices for supplies of the 
Payments on the RA External Debt

\begin{tabular}{|c|c|c|c|c|}
\hline & \multicolumn{2}{|c|}{ Principal repayments on external debt } & \multicolumn{2}{c|}{ Interest rate } \\
\hline & bln AMD & \% in budget expenses & bln AMD & \% in budget expenses \\
\hline 2018 & 158,4 & 11,6 & 120,3 & 8,8 \\
\hline 2019 & 185,7 & 12,4 & 136,7 & 9,1 \\
\hline 2020 & 197,3 & 12 & 146,6 & 8,9 \\
\hline 2025 & 486,9 & 27,1 & 176,1 & 9,8 \\
\hline
\end{tabular}

Source: Ministry of Finance of the RA, report on the foreign debt.

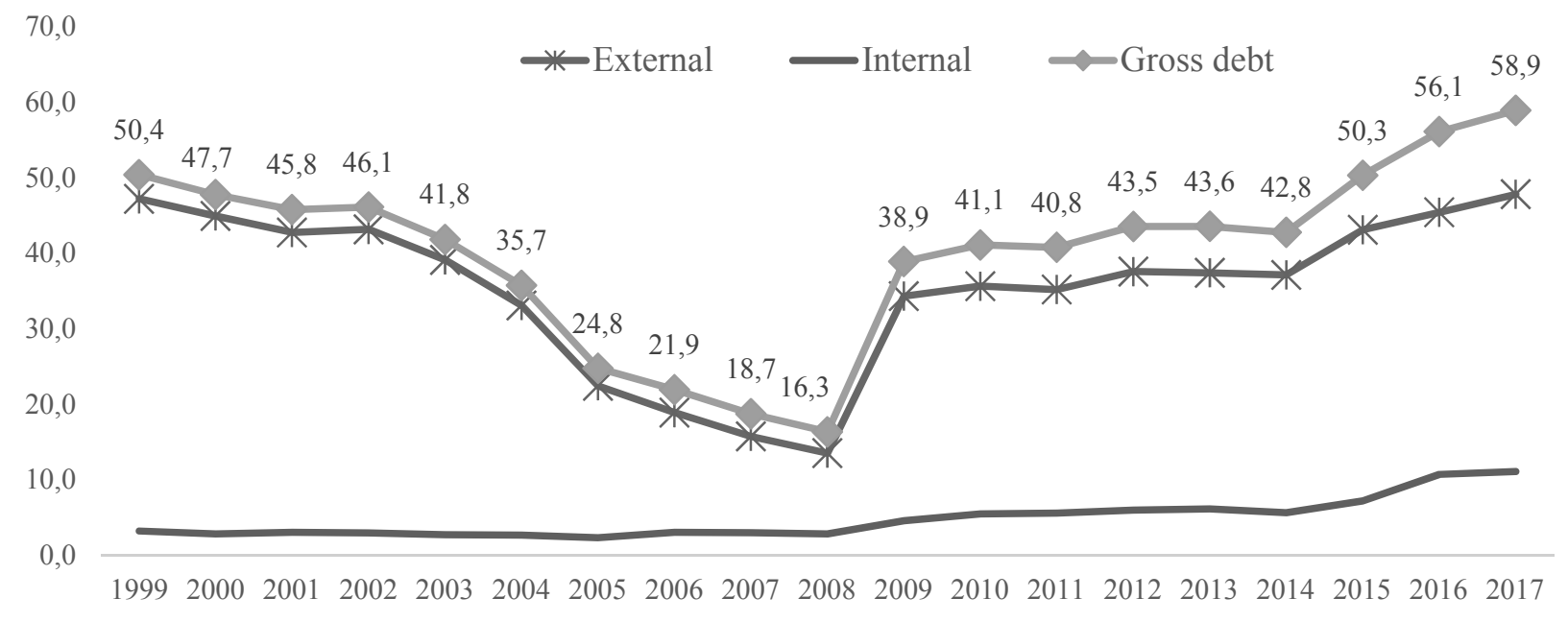

\section{Fig. 4. The Government Debt of RA (\% in GDP)}

Source: Ministry of Finance of RA, report on the foreign debt (accessed 10.09.2018).

metal raw materials (non-ferrous metals) ${ }^{2}$ exported from Armenia through offshore organizations. The volume of foreign currency outflow from Armenia through this channel amounts to about $11-12 \%$ to GDP yearly.

An important channel for the inflow of foreign currency into the country is foreign debt. In Armenia, more than 50 per cent of the external national debt is the aggregate debt of the Government and the Central Bank. At the same time, in the upcoming years, the costs of servicing the external debt will be a significant burden, especially for the state budget (see Table 1).

However, as mentioned above, an inefficient taxation system creates significant risks associated with the repayment of the external public debt. It is clear that in

\footnotetext{
${ }^{2}$ Dev Kar, and Joseph Spanjers, Illicit Financial Flows from Developing Countries: 2004-2013, Global Financial Integrity (December 2015). URL: http://www.gfintegrity.org/report/illicit-financial-flows-from-developing-countries-2004-2013/ (accessed 27.09.2018).
}

the case of preserving current fiscal and monetary policies the external debt will significantly limit the capacity to implement an expansionary fiscal policy and reduce the potential for economic growth. Besides, a significant increase in the volume of external borrowings after 2008 should also have affected the currency policy.

Fig. 4 shows that since 2009 the government debt in Armenia has been consistently increasing. As of the end of 2017, the gross public debt approached to the critical limit of $60 \%$ of GDP. Moreover, the gross national external debt, an important channel for the foreign currency inflow into the country, also tends to grow (see fig. 5). Besides, during the period from January 2015 to the end of June 2018 the volatility of the Armenian dram exchange rate varied around zero within 1 percent, which again indicates the implementation of the non-market policy of exchange rate targeting "in manual mode", in spite of the dynamics and trends in changes in the currency structure of monetary aggregates. 


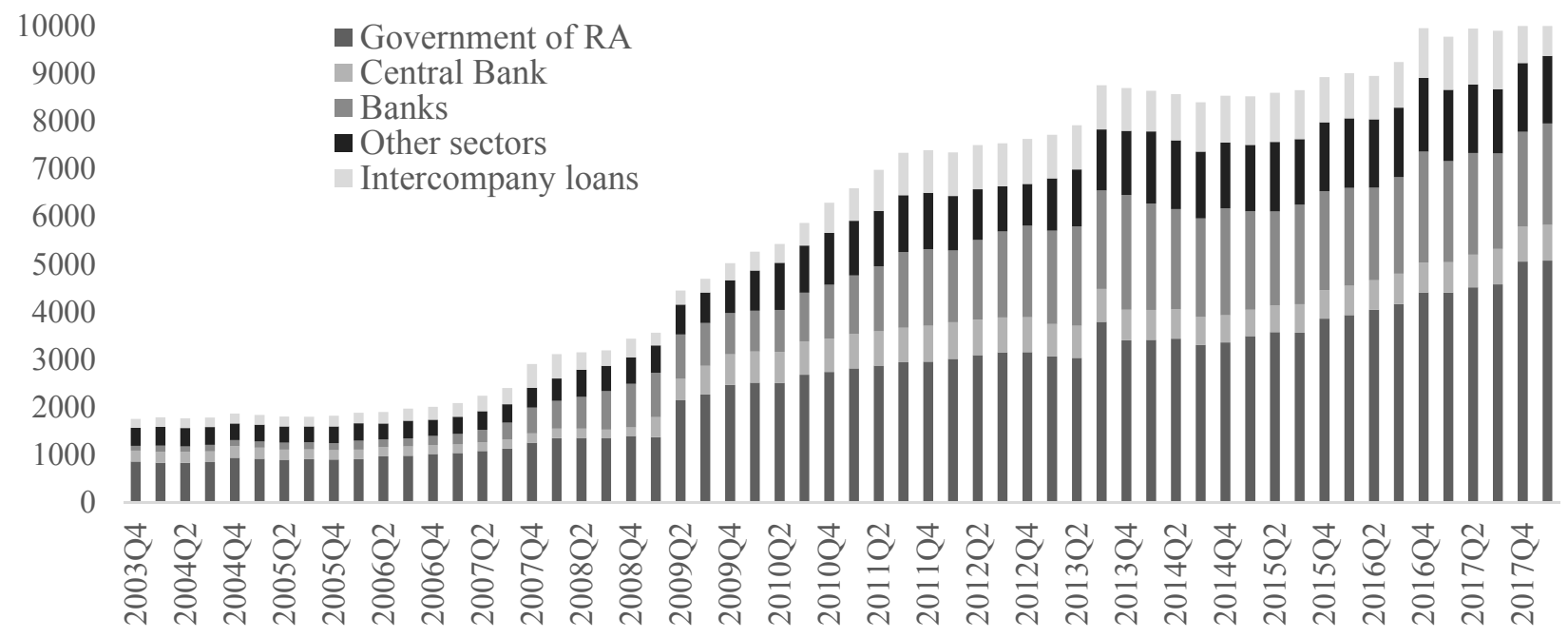

Fig. 5. International Investment Position on Armenia's. Gross External Debt (mln USD)

Source: Database of the Central Bank of RA. URL: http://www.cba.am/ (accessed 27.09.2018).

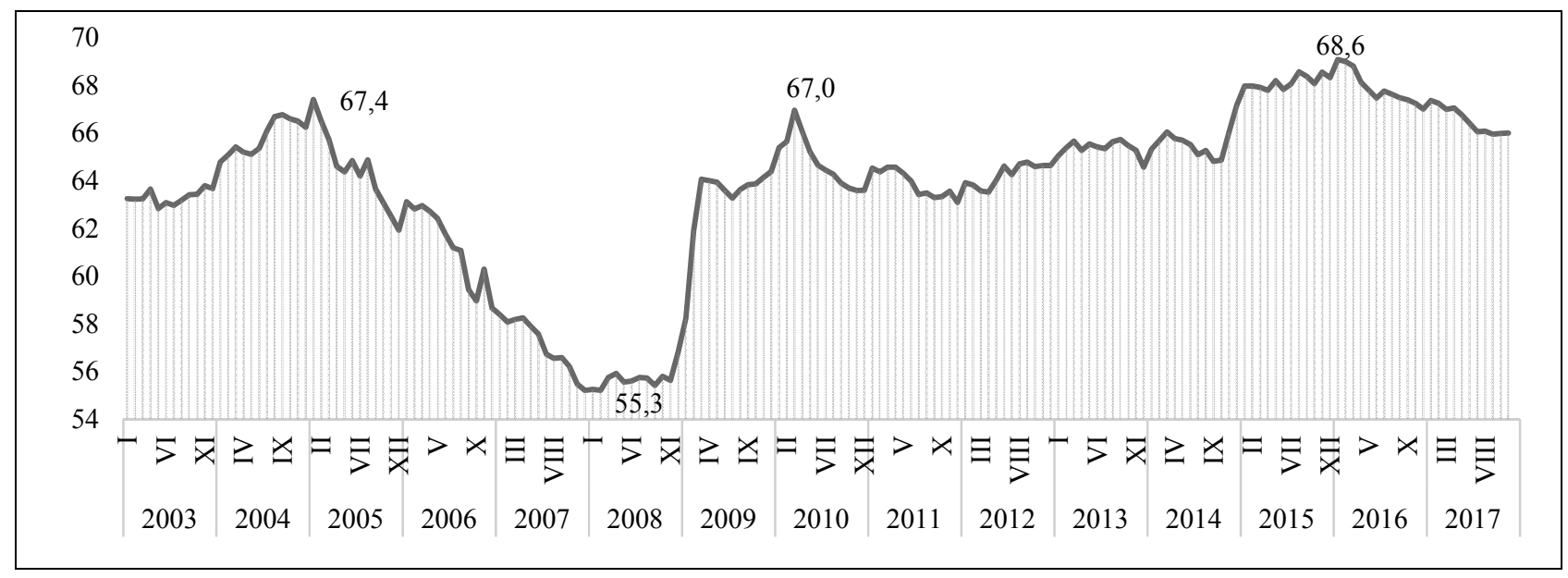

Fig. 6. The level of dollarization in Armenia

Source: Database of the Central Bank of RA. URL: http://www.cba.am/ (accessed 10.09.2018).

An important factor that also has an impact on the exchange rate is the high level of dollarization of the economy, particularly that of savings. It is remarkable that the Central Bank's efforts to strengthen the exchange rate of the national currency led to some positive results in the fight against dollarization. So, as of the end of 2008 , the level of dollarization was $55.3 \%$ (see fig. 6). However, the global financial crisis and the lack of public confidence in the activities of the Central Bank of Armenia and in the local currency unit led to the growth of the level of dollarization in Armenia which already reached $67 \%$ in the middle of 2009 . This situation, among other things, is a significant obstacle to the effective implementation of monetary policy.

Taking into consideration the specifics of monetary regulation in Armenia, the currency and monetary regulation implemented by the Central Bank of Ar- menia should also be mentioned among the factors that have a significant impact on the exchange rate of the Armenian dram.

A striking example of the monetary authorities' interference in the currency market is the policy of reserve requirement on foreign currency liabilities, which, in fact, suspended the currency crisis that arose under the influence of exogenous factors associated with the sharp devaluation of the Russian ruble in December 2014 (see fig. 7). Due to the validity of this instrument, since December 2014 the banking system has been forced to freeze a significant amount of money in the accounts of the CBA (exceeding $5 \%$ of the GDP ${ }^{3}$ and

\footnotetext{
${ }^{3}$ Database of the Central Bank of Armenia. URL: https://www. cba.am/am/SitePages/statmonetaryfinancial.aspx (accessed 27.09.2018).
} 


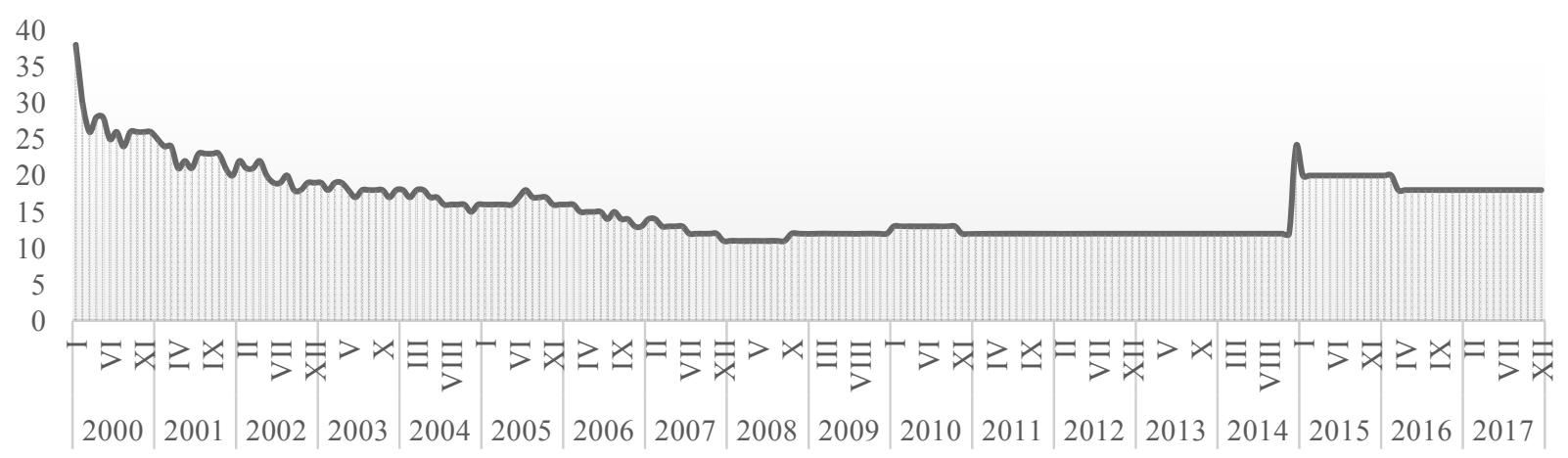

Fig. 7. The reserve requirement on foreign currency liabilities in RA

Source: Database of the Central Bank of RA. URL: http://www.cba.am/ (accessed 27.09.2018).

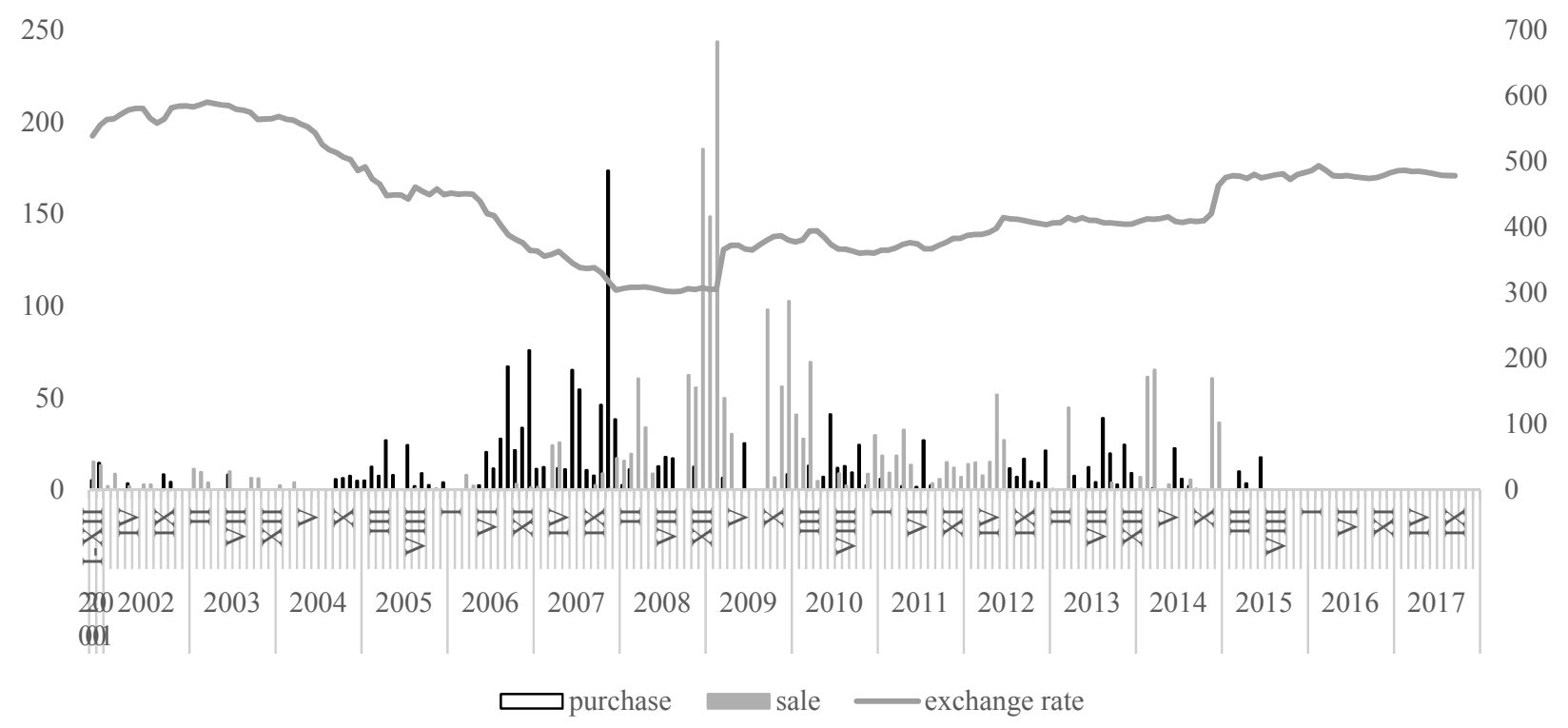

\section{Fig. 8. Currency interventions of CBA}

Source: Database of the Central Bank of RA. URL: http://www.cba.am/ (accessed 10.09.2018).

converted to the Armenian national currency, according to the reserve requirement) transferring currency and interest risks to its depositors. On 17 December 2014, the Central Bank raised the reserve requirement on foreign currency liabilities from $12 \%$ to $24 \%$ on the condition that reserves would be allocated to the Central Bank exclusively in Armenian drams (previously $6 \%$ was required to be allocated in AMD, and the remaining $6 \%$ in deposit currency), which was the reason for dramatic strengthening of the dram literally on the next day. As a result, on December 18 the exchange rate of the US dollar fell by 30.2 points and was fixed at around 497 AMD for 1 USD. The ratio of reserve requirement on AMD deposits remained at the level of $2 \%$. A few days later, on December 23 the CBA changed the rate of the reserve requirement from $24 \%{ }^{4}$

\footnotetext{
${ }^{4}$ Database of the Central Bank of Armenia. URL: https://www. cba.am/am/SitePages/regbanks.aspx (accessed 27.09.2018).
}

to $20 \%$, which was valid until October 2016 , when the rate was lowered to $18 \%$ (it is still valid).

Thus, the most effective instrument of influence on the exchange rate of the Armenian dram in a crisis situation has become the crude instrument of monetary policy.

However, the artificial appreciation of the exchange rate of the national currency, which is carried out by the Central Bank, has led to significant negative consequences. Certainly, this policy, to some extent, restrained the money supply growth and, accordingly, to a certain extent, reduced inflationary pressure. However, the tightening of currency control weakened the export potential of the Armenian economy. It is also necessary to mention one of the most important conditions for the successful implementation of inflation targeting, namely a free-floating exchange rate. In this sense, de facto applying tight exchange regulation, the Central Bank of Armenia initially excludes the possibility of 


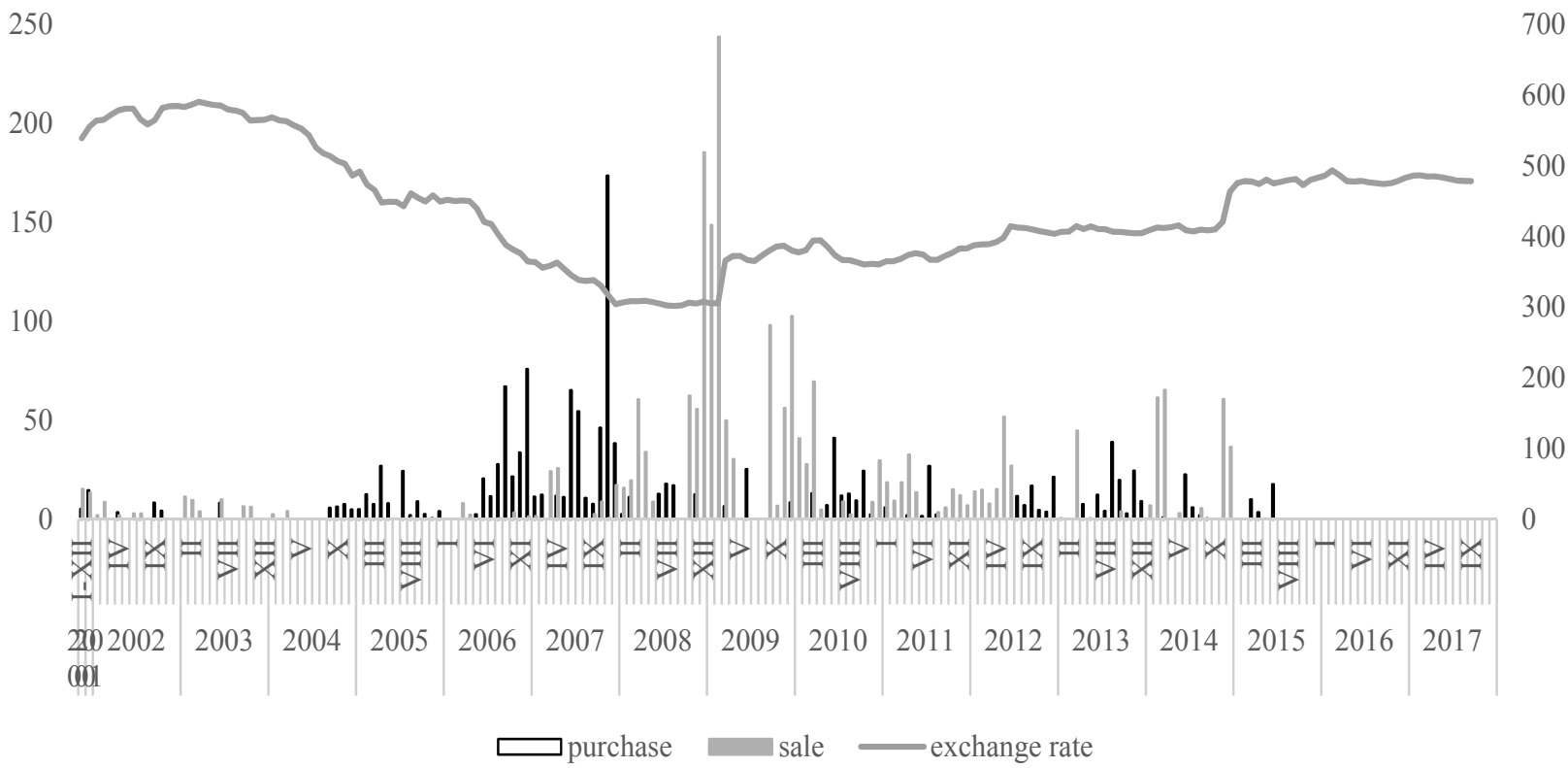

\section{Fig. 9. International currency reserves of the CB ( $m \ln$ USD), exchange rate and the number of currency} transactions on the foreign exchange market NasdaqOMX Armenia (mln USD)

Source: Database of the Central Bank of RA. URL: http://www.cba.am/ (accessed 10.09.2018).

implementation of effective monetary policy under inflation targeting.

Not surprisingly, under such circumstances, the only way to maintain the budget balance is to increase public debt, which from 2008 to the end of 2015 increased from $16.3 \%$ in GDP to $50.4 \%{ }^{5}$, and reached $60 \%$ at the end of 2017.

Earlier, especially in the period from the end of 2005 up to the end of 2014, the most effective instrument to influence the currency market in the long-term was currency interventions, which the CBA periodically resorted to throughout the implementation of the monetary policy.

It is clear that from the end of 2005 beginning of 2006 the policy of monetary authorities was aimed at strengthening the exchange rate of the national currency. The activity of the Central Bank in the foreign exchange market during this period is unprecedented! The volume of sales increased from 105,6 million US dollars in 2005 to 799 million US dollars in $2009^{6}$ (see fig. 8). Such actions in the foreign exchange market by the Central Bank led to a significant strengthening of the exchange rate of the national currency. Since 2003 the appreciation of the Armenian dram against the US dollar was $52 \%$. From the end of 2007 to the beginning of 2008 the Central Bank was actually implementing a rigid exchange rate policy. Another peak of activity is

\footnotetext{
${ }^{5}$ Ministry of Finance of RA. URL: http://www.minfin.am/ minfin.am/index.php?cat=207 \&lang=1 (accessed 27.09.2018). ${ }^{6}$ Source: Data according to the official website of the Stock Exchange of RA. URL: http://www.nasdaqomx.am (accessed 27.09.2018).
}

observed at the end of 2014 when, by actively interfering in the foreign exchange market, the Central Bank tried again to prevent the devaluation of the Armenian dram against the U.S. dollar caused by the devaluation of the Russian ruble against the U.S. dollar.

By March 2009, the Central Bank of Armenia had faced a serious shortage of international reserves amounting to 1,331.4 million US dollars ${ }^{7},-$ almost a critical minimum level (see fig. 9).

This situation made the Central Bank of Armenia decrease its activity in the foreign exchange market, which brought about the devaluation of the exchange rate of the national currency in March 2009 by approximately $21 \%^{8}$. This situation has led not only to the significant volatility of the exchange rate, but also to a decrease in confidence towards the monetary authorities, financial and macroeconomic imbalances, increased inflation expectations, and, finally, serious negative repercussions in the economy as a whole. Moreover, the situation repeated by the end of 2014 .

To sum up, it can be concluded that among the factors directly affecting the exchange rate of the Armenian dram one can distinguish market channels, as well as not market-based mechanisms of influence applied by the monetary authorities. In this regard, the next step in this paper will be an assessment of the factors discussed above in terms of their impact on the volatility of the foreign exchange rate.

\footnotetext{
${ }^{7}$ URL: http://www.cba.am/ (accessed 27.09.2018).

${ }^{8}$ URL: http://www.cba.am/ (accessed 27.09.2018).
} 


\section{FOREIGN EXCHANGE RATE MODELLING. THE CASE OF ARMENIA. METHODOLOGY}

In order to conduct effective monetary policy, central banks are interested in the constant improvement of the methodology of macroeconomic forecasting. Forecasting exchange rates are one of the crucial factors that the policy-makers should take into account. In contemporary research, economists apply mathematical models that allow revealing hidden regularities in statistical data and building forecasts on their basis.

Exchange rate forecasting has been of the central interest to economists for many years. The existing literature suggests different approaches to modelling the relationship between macroeconomic indicators and the exchange rate. In recent years one of the most commonly used approaches to exchange rate forecasting by academic researchers and central banks has been the Vector autoregression (VAR) model [1-4]. The VAR model has become broadly used by researchers after the seminal work of Sims [1], where he stated that VAR is a suitable tool for analyzing and forecasting economic and financial time series. Besides, one of the advantages of the VAR model is its flexibility, since we can include in it as many endogenous variables as necessary.

In contrast to the models based on differential equations, the proposed model has the following advantages: the ease of identification, implementation, and solution to the problem of overfitting a model. The methodology of building autoregressive models has advanced greatly, mainly due to the simplicity and universality of the methods.

The unconstrained Vector autoregression model of $\mathrm{N}$ endogenous variables of order $\mathrm{p}-\operatorname{VAR}(\mathrm{p})$ can be represented by the following equation:

$$
y_{t}=c+A_{1} y_{t-1}+A_{2} y_{t-2}+\cdots+A_{p} y_{t-p}+v_{t},
$$

where $\mathrm{y}_{\mathrm{t}}$ is $N \times 1$ vector of $N$ exoplanetary variables, c is $N \times 1$ vector of constant coefficients; $\mathrm{A}_{1}, \mathrm{~A}_{2}, \ldots, \mathrm{A}_{\mathrm{p}}$ are $N \times N$ matrixes of estimated parameters for different lag orders $-1=1,2, \ldots, \mathrm{p} ; \mathrm{v}_{\mathrm{t}}$ is $N \times 1$ vector of white noise, $v_{t} \sim N\left(0, \sigma^{2} I_{n \times n}\right)$.

It is known that the parameters of an unconstrained vector autoregressive model can be estimated by the ordinary least squares method [5]. The VAR-process with lag $\mathrm{p}$ has an important feature which is stability. It means that the stationary time series generated from this process would have time-invariant means, variances and covariance structure when given sufficient starting values.

In the framework of this research, the sample period runs from 2001Q1 to 2017Q4. In order to build a
VAR model, the authors took into account the analysis conducted in the previous section. The estimation of the parameters, as well as the described tests, was performed using the statistical software STATA 14. All variables were tested and cleared of seasonality. Moreover, when implementing a VAR model, all the time series should be stationary. In order to check the stationarity of the variables, the authors have used the augmented Dickey-Fuller test [7], which tests the variables for the presence of unit root. The auxiliary regression for the unit root test is given as follows:

$$
\Delta y_{t}=z_{t}{ }^{\prime} \delta+\rho y_{t-1}+\sum_{i=1}^{p} \beta_{i} \Delta y_{t-i}+v_{t} .
$$

where $z_{t}$ are optional exogenous variables that may consist of a constant, or a constant and a time trends; $\delta, \rho, \beta_{i}(i=1,2, \ldots, p)$ are unknown parameters to be estimated; $v_{t}$ is the white noise.

The null and alternative hypotheses are as follows: $H_{0}: \rho=0, H_{1}: \rho<0$.

After testing the variables in levels, it became clear that they are not stationary. In order to make them stationary, the authors have used the first difference method. Table 2 represents the transformation of the time series.

After the transformation, all the variables were double checked for the presence of a unit root, and it was made sure that they became stationary.

The VAR model is highly sensitive to the lag length involved. Different researchers suggest several methods to choose the optimum lag length. In this paper, the appropriate lag length was taken based on Schwarz's Bayesian information criterion (SBIC), the Akaike information criterion (AIC), and the Hannan-Quin information criterion (HQIC). These criteria can be determined as follows [6]:

$$
\begin{gathered}
S B I C=-\frac{2 \hat{l}}{n}+\frac{p \log n}{n}, \\
A I C=-\frac{2 \hat{l}}{n}+\frac{2 p}{n}, \\
H Q I C=-\frac{2 \hat{l}}{n}+\frac{2 p[\log (\log n)]}{n},
\end{gathered}
$$

where $\hat{l}$ is the value of the log-likelihood with p parameters and $n$ observations.

In statistics, the root mean squared error is a commonly used measure that estimates the difference between the values forecasted by the model and the actual values from the series that were used to generate the model. It can be defined by the following function: 
The list of used variables

\begin{tabular}{|l|c|c|}
\hline & Transformation & Seasonal adjustment \\
\hline Exchange rate AMD/USD & $\Delta \ln$ Yes \\
\hline Exchange rate RUB/USD & $\Delta \ln$ Yes \\
\hline Export & $\Delta \ln$ & Yes \\
\hline Import & $\Delta \ln$ & Yes \\
\hline Interest rate & $\Delta$ & Yes \\
\hline GDP & $\Delta \ln$ & Yes \\
\hline Foreign deposits & $\Delta \ln$ & No \\
\hline CPI & No & Yes \\
\hline Foreign direct investments & $\Delta \ln$ & Yes \\
\hline Inflow of remittances & $\Delta \ln$ & Yes \\
\hline Outflow of remittances & $\Delta \ln$ & Yes \\
\hline Brent oil prices & $\Delta \ln$ & Yes \\
\hline Gross external debt & $\Delta \ln$ & \\
\hline
\end{tabular}

Source: calculations of the authors.

$$
R M S E=\sqrt{\frac{\sum_{t=1}^{n}\left(\hat{y}_{t}-y_{t}\right)^{2}}{n}},
$$

where $\hat{y}_{t}$ are the forecasting results and $y_{t}$ are the actual values.

All in all, taking into account the adjusted R squared, RMSE, as well as the SBIC, AIC, HQIC criteria the authors have built a VAR (2) model that includes the following variables: the exchange rate of the Armenian dram, deposits in foreign currency, the volume of imports, international reserves of the Central Bank of Armenia, the volume of the inflow of foreign direct investments, inflow and outflow of remittances, as well as a binary variable for the interventions of the Central Bank.

In order to ensure that the VAR is stable, the authors have applied Johansen's cointegration test to confirm that the series are not cointegrated or cointegrated with an "N" relationship. In addition, the research team also uses a residual correlation test to determine whether the residuals are correlated. The model was also tested against heteroscedasticity and the normality of distribution. All tests proved that the model is stable.

\section{A VAR MODEL}

As it was mentioned in the previous section, the authors have built a VAR (2) model for the exchange rate of the Armenian dram, which includes the following factors: deposits in foreign currency, the volume of imports, international reserves of the Central Bank of Armenia, the volume of the inflow of foreign direct investments, inflow and outflow of remittances as well as I binary variable for the interventions of the Central Bank.

The equation of the model looks like this:

$$
\begin{gathered}
\text { NER }=0.368 N E R(1)+0.197 N E R(2)-0.004 F D I(1)+ \\
+0.01 F D I(2)+0.094 \operatorname{Im}(1)+0.094 \operatorname{Im}(2)- \\
-0.076 \text { Rem_in }(1)-0.104 \text { Rem_in }(2)+ \\
+0.028 \text { Rem_out }(1)-0.047 \operatorname{Rem} \_ \text {out }(2)+ \\
+0.159 F D(1)-0.264 F D(2)+0.007 C B(1)+ \\
+0.0004 C B(2)-0.15 \operatorname{IR}(1)- \\
-0.048 I R(2)+0.0034 .
\end{gathered}
$$

The estimation results suggest that the changes in foreign deposits and in the international reserves of the Central Bank of RA, as well as the changes in the import volumes, have the biggest impact on the changes of the nominal exchange rate of the Armenian dram.

Fig. 10 presents the actual values of the exchange rate of Armenia (NER), the estimated values by the VAR (2) model and a scenario that assumes that there were no interventions by the Central Bank of Armenia. The presented scenario suggests that a floating exchange 


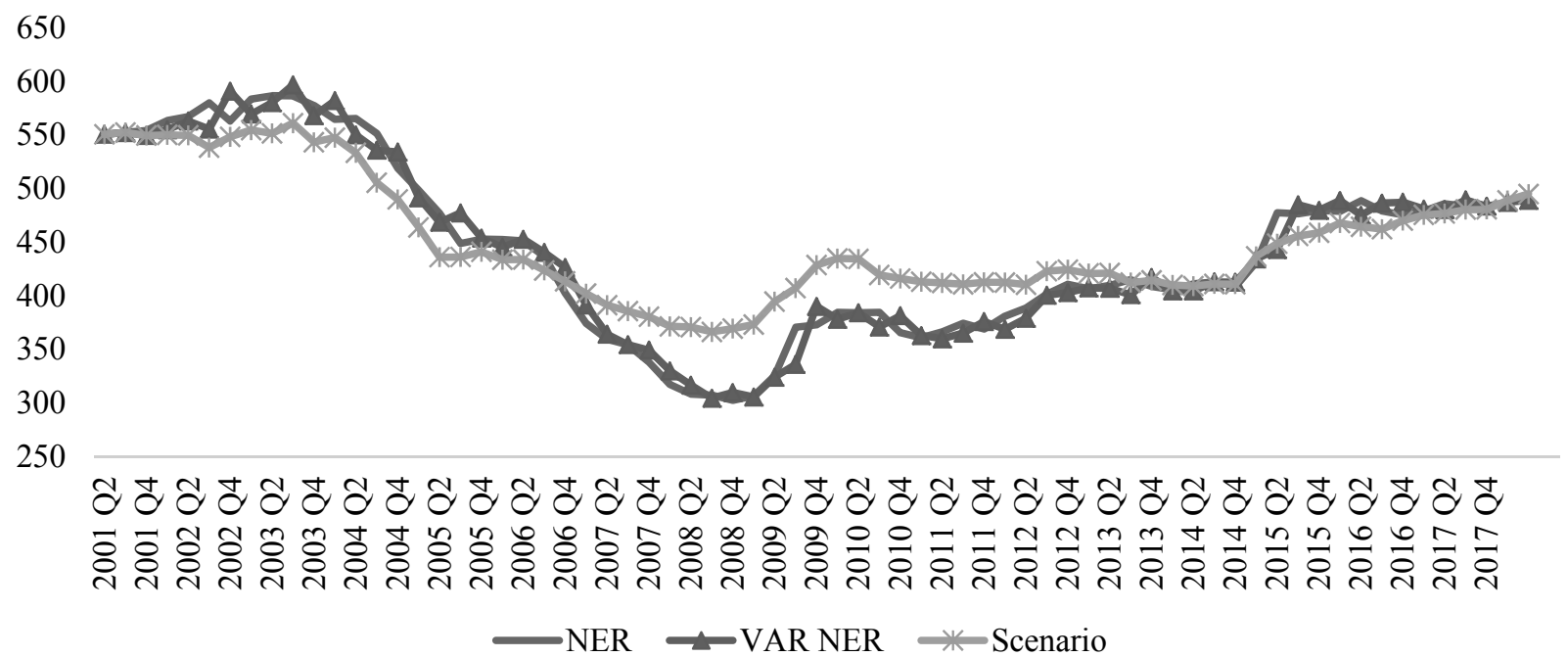

\section{Fig. 10. Actual and estimated values of the nominal exchange rate of the Armenian Dram}

Source: Calculations of the authors.

rate is better for absorption of the external shocks in Armenia and may prevent exchange rate overshooting, hence currency crisis.

It is seen that if the Central Bank of Armenia had implemented a non-interference policy and had not used the reserve requirement instrument in order to manage the exchange rate, conducting floating exchange rate policy instead, the adjustment of the exchange rate to the external shocks would have gone smoother. In the period of the 2008-2009 and 2014-2015 devaluation of the Armenian dram could have been without overshooting. In other words, the results of the research point out that there is a need for change in the approaches to the monetary and currency regulation in Armenia.

Obviously, the fixed exchange rate policy creates deep problems that are difficult to overcome. Solely the market-based exchange rate of the national currency will allow to restore the purchasing power parity of Armenian goods in the Russian market, improve the comparative advantages of domestic producers in the domestic market, and take advantage of all the benefits associated with integration in the EAEU [8]. For this purpose, it is necessary to:
Review the current monetary policy, adhere to a target corresponding to real inflation in the country in order to stimulate economic growth. At the same time, it is necessary to target a significant gap between inflation and the rate of devaluation of the dram, which will stimulate exports, as well as an increase in the real income of remittance-dependent individuals.

Abandon the fixed exchange rate policy by nonmarket methods and implement a free-floating exchange rate and non-interference policies (foreign exchange interventions are allowed solely for equalizing peak jumps and avoiding feverish demand in the foreign exchange market), which in the shortterm perspective will protect the financial market of Armenia from exogenous risks and will restore the competitiveness of Armenian goods in foreign markets, primarily in Russia. At the same time, appropriate calculations should be made to identify the "price of the issue," that is to determine the resources necessary to compensate the possible losses from inflation growth due to the devaluation of the Armenian dram exchange rate, for example, through external debt and/or sequestration of the state budget.

\section{ACKNOWLEDGEMENTS}

This work was supported by Russian-Armenian University within the framework of the grant of the Ministry of Education and Science of the Russian Federation. Yerevan, Armenia.

\section{БЛАГОДАРНОСТЬ}

Исследование выполнено в Российско-Армянском университете за счет средств, выделенных в рамках субсидии МОН РФ на финансирование научно-исследовательской деятельности Российско-Армянского (Славянского) университета. Ереван, Армения. 


\section{APPENDIX \\ VECTOR AUTOREGRESSIVE MODEL - RESULTS}

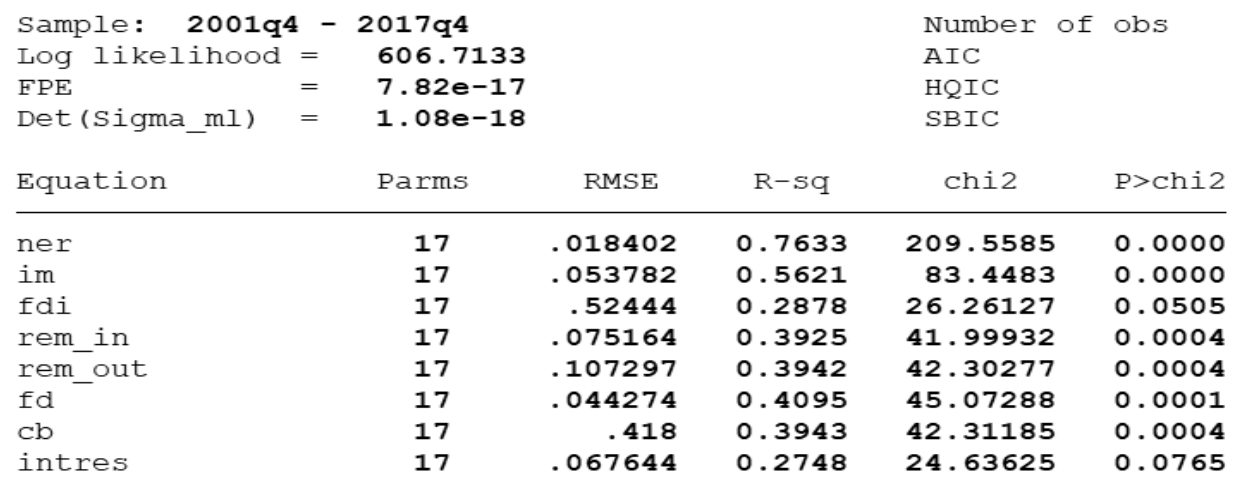

\begin{tabular}{l|llll}
\hline & Coef. Std. Err. & P & [95\% Conf. Interval] \\
\hline
\end{tabular}

\begin{tabular}{|c|c|c|c|c|c|c|}
\hline \multicolumn{7}{|c|}{ ex } \\
\hline L1. & .3684241 & .1037936 & 3.55 & 0.000 & .1649925 & .5718558 \\
\hline L2. & .1971745 & .0926658 & 2.13 & 0.033 & .0155528 & .3787961 \\
\hline \multicolumn{7}{|l|}{ im } \\
\hline L1. & .0942743 & .0404113 & 2.33 & 0.020 & .0150697 & .1734789 \\
\hline L2. & .0936302 & .0359173 & 2.61 & 0.009 & .0232336 & .1640268 \\
\hline \multicolumn{7}{|l|}{ fdi } \\
\hline L1. & -.0040358 & .0043096 & -0.94 & 0.349 & -.0124826 & .0044109 \\
\hline L2. & .0101893 & .0042499 & 2.40 & 0.017 & .0018596 & .018519 \\
\hline \multicolumn{7}{|l|}{ rem_in } \\
\hline $\bar{L} 1$. & -.0765642 & .031931 & -2.40 & 0.016 & -.1391478 & -.0139805 \\
\hline L2. & -.1041283 & .0347153 & -3.00 & 0.003 & -.172169 & -.0360876 \\
\hline \multicolumn{7}{|l|}{ rem_out } \\
\hline L1. & .0277482 & .0212432 & 1.31 & 0.191 & -.0138877 & .0693841 \\
\hline L2. & -.0473978 & .0216532 & -2.19 & 0.029 & -.0898373 & -.0049583 \\
\hline \multicolumn{7}{|l|}{$\mathrm{fd}$} \\
\hline L1. & .1593284 & .0541701 & 2.94 & 0.003 & .0531569 & .2654998 \\
\hline L2. & -.2635593 & .0560183 & -4.70 & 0.000 & -.3733531 & -.1537654 \\
\hline \multicolumn{7}{|l|}{$\mathrm{cb}$} \\
\hline L1. & .007181 & .0056641 & 1.27 & 0.205 & -.0039204 & .0182824 \\
\hline L2. & .0003978 & .0057741 & 0.07 & 0.945 & -.0109192 & .0117149 \\
\hline \multicolumn{7}{|l|}{ intres } \\
\hline L1. & -.1496373 & .033993 & -4.40 & 0.000 & -.2162625 & -.0830122 \\
\hline L2. & -.0481398 & .0401439 & $-1 \cdot 20$ & 0.230 & -.1268205 & .0305408 \\
\hline _cons & .0034014 & .0051389 & 0.66 & 0.508 & -.0066706 & .0134735 \\
\hline
\end{tabular}

\section{REFERENCES}

1. Sims C.A. Comparison of interwar and postwar business cycles: Monetarism reconsidered. The American Economic Review. 1980;70(2):250-257.

2. Bernanke B.S., Mihov I. Measuring monetary policy. The Quarterly Journal of Economics. 1998;113(3):869-902. DOI: $10.1162 / 003355398555775$

3. Bernanke B.S., Blinder A.S. The federal funds rate and the channels of monetary transmission. The American Economic Review. 1992;82(4):901-921.

4. Christiano L., Eichenbaum M., Evans C. The effects of monetary policy shocks: Evidence from the flow of funds. The Review of Economics and Statistics. 1996;78(1):16-34. DOI: 10.2307/2109845 
5. Hamilton J.D. Time series analysis. Princeton, NJ: Princeton University Press; 1994. 816 p.

6. Yongtao Y. Exchange rate forecasting model comparison: A case study in North Europe. Master thesis in statistics. Uppsala: Uppsala University; 2011. 34 p. URL: http://www.diva-portal.se/smash/get/diva2:422759/ FULLTEXT01.pdf (accessed 05.09.2018).

7. Dickey D.A., Fuller W.A. Distribution of the estimators for autoregressive time series with a unit root. Journal of the American Statistical Association. 1979;74(366):427-431. DOI: 10.2307/2286348

8. Sandoyan E. M. The prospects of currency regulation policy alternative approaches in Armenia. Vestnik Finansovogo universiteta $=$ Bulletin of the Financial University. 2017;21(1):87-90. (In Russ.).

\section{ABOUT THE AUTHORS}

Edvard M. Sandoyan - Dr. Sci. (Econ.), professor, Director of the Institute of Economics and Business, Russian-Armenian (Slavonic) University, Yerevan, Armenia

edward.sandoyan@rau.am

Mariam A. Voskanyan - Dr. Sci. (Econ.), associate professor, Head of Economics and Finance Department Russian-Armenian (Slavonic) University, Yerevan, Armenia

mariam.voskanyan@rau.am

Ani G. Galstyan - PhD student, Economics and Finance Department, Russian-Armenian (Slavonic) University, Yerevan, Armenia

ani.galstyan@rau.am

\section{ИНФОРМАЦИЯ ОБ АВТОРАХ}

Эдвард Мартинович Сандоян - доктор экономических наук, профессор, директор Института экономики и бизнеса, Российско-Армянский (Славянский) университет, Ереван, Армения edward.sandoyan@rau.am

Мариам Амбарцумовна Восканян - доктор экономических наук, доцент, заведующая кафедрой экономики и финансов, Российско-Армянский (Славянский) университет, Ереван, Армения

mariam.voskanyan@rau.am

Ани Гамлетовна Галстян - аспирант кафедры экономики и финансов, Российско-Армянский (Славянский) университет, Ереван, Армения

ani.galstyan@rau.am

\section{The declared contribution of the authors:}

Sandoyan E.M.- scientific management; development of conceptual proposals for the revision of approaches to currency regulation in order to stimulate economic growth in the long term.

Voskanyan M.A. - development of approaches to currency regulation from the point of view of stimulating economic growth in the long term, taking into account the participation of Armenia in the EAEU; development of scenarios of the impact of currency regulation on changes in economic growth in Armenia.

Galstyan A.G.- work on the econometric model and data processing; work on the English version of the article.

\section{Заявленный вклад авторов:}

Сандоян Э.М.- научное руководство, разработка концептуальных предложений по пересмотру подходов к валютному регулированию с целью стимулирования экономического роста в долгосрочной перспективе.

Восканян М.А.- разработка подходов к валютному регулированию с точки зрения стимулирования экономического роста в долгосрочной перспективе с учетом участия Армении в ЕАЭС; разработка сценариев воздействия валютного регулирования на изменения в экономическом росте в Армении.

Галстян А.Г.- работа над эконометрической моделью, обработка данных, работа над англоязычной версией статьи.

The article was received 23.06.2018; accepted for publication 08.10.2018.

The authors read and approved the final version of the manuscript.

Статья поступила 23.06.2018; принята к публикации 08.10.2018.

Авторы прочитали и одобрили окончательный вариант рукописи. 